\title{
MUTU KIMIA TERIPANG HITAM (Holothuria vacabunda) ASAP PADA BERBAGAI LARUTAN KOSENTRASI GARAM
}

\author{
Finarti $^{1)}$, Anita Treisya Aristawati ${ }^{1)}, \operatorname{Renol}^{1)}$ dan Nirtayanti ${ }^{1)}$ \\ ${ }^{1}$ Sekolah Tinggi Perikanan dan Kelautan-STPL, \\ Jl. Soekarno Hatta KM 6 Palu, Sulawesi Tengah, Indonesia \\ renolstpl@yahoo.com
}

\begin{abstract}
Abstrak
Pengasapan adalah salah satu cara memasak, memberi aroma, atau proses pengawetan makanan, terutama daging, ikan dan hasil laut lainnya. Makanan diasapi dengan panas dan asap yang dihasilkan dari pembakaran kayu, dan tidak disimpan dekat dengan api agar tidak terpanggang atau terbakar. Penelitian ini bertujuan untuk mengetahui mutu kimia teripang hitam asap dengan berbagai konsentrasi larutan garam yang berbeda. Sedangkan manfaat penelitian ini diharapkan dapat memberikan informasi ilmiah tentang analisa mutu kimia teripang setelah pengasapan yang mendapat perlakuan garam yang berbeda. Penelitian ini menggunakan Rancangan Acak Lengkap (RAL) dengan 4 perlakuan. Sebagai perlakuan adalah berbagai konsentrasi larutan garam dengan level $T A_{1}(5 \%), T A_{2}$ (10\%), $\mathrm{TA}_{3}(15 \%)$, dan $\mathrm{TA}_{4}(20 \%)$ dan pengulangan sebanyak 4 kali sehingga jumlah satuan percobaan sebanyak 16 unit percobaan. kadar air teripang hitam pada kosentrasi garam yang berbeda berkisar antara $9.44-12.09 \%$. Kadar air teripang hitam pada kosentrasi garam yang berbeda dengan perlakuan $5 \%\left(\mathrm{TA}_{1}\right)$ sebesar $12.09 \%$ merupakan kadar air yang tertinggi yang diperoleh dalam penelitian ini. Sedangkan kadar air yang terendahnya pada kosentrasi garam $20 \%\left(\mathrm{TA}_{4}\right)$ sebesar $9.44 \%$. kadar abu tertinggi diperoleh pada kosentrasi garam $20 \%\left(\mathrm{TA}_{4}\right)$ sebesar $25.15 \%$ serta terendah diperoleh pada kosentrasi $5 \%\left(T_{1}\right)$ sebesar $21.83 \%$. kadar protein teripang hitam berkisar antara $7.51-8.78 \%$. Kadar protein teripang hitam pada kosentrasi garam $20 \%\left(\mathrm{TA}^{4}\right)$ sebesar $8.78 \%$ merupakan kadar protein tertinggi yang diperoleh dalam penelitian ini. Sedangkan kadar protein yang terendah diperoleh darikosentrasi garam $5 \%\left(T A^{1}\right)$ sebesar $7.51 \%$.
\end{abstract}

Kata Kunci : Teripang Hitam, Pengasapan, Garam

\section{PENDAHULUAN}

Timun laut atau teripang adalah biota laut yang bergerak lambat, hidup pada dasar substrat pasir, lumpur pasiran maupun dalam lingkungan terumbu yang merupakan salah satu sumber protein hewani dan telah lama dikonsumsi oleh masyarakat didalam maupun diluar negeri.

Teknologi pengolahan teripang umumnya dilakukan dengan metode pengeringan dan pengasapan. Konsumen lebih menyukai rasa dan bau spesifik yang dilakukan dengan cara pengasapan, sekaliggus pengasapan juga dapat menurunkan kandungan air pada produk. Pengasapan dapat dilakukan dengan lemari
Pengasapan waktu 10-20 jam dengan suhu $60-80^{\circ} \mathrm{C}$. Nelayan pengolahan tradisional menggunakan alat pengasap terbakar (panas yang dihasilkan dari api bukan asap), menggunakan cara ini kurang efektif, selain itu teripang yang diasap akan terkontaminasi dengan kotoran dari luar serta pemakaian asapnya menjadi tidak efisien, karena lebih banyak keluar dari lemari pengasapan dan celah-celah yang tidak tertutup. Teripang asap yang berkualitas tinggi dipengaruhi oleh bahan pengasap, salah satu bahan yang baik digunakan dalam mengasapi teripang yaitu Serbuk gergaji dan daun jambu biji segar 
yang ditaburkan diatas bara arang. (Wibowo, 2000).

Teripang memiliki nilai gizi yang tinggi dan cocok dikonsumsi sebagai bahan pangan. Dikarenakan teripang memiliki kandungan protein yang sangat tinggi sekaligus rendah lemak. Hal ini menyebabkan teripang menjadi primadona di dunia ekspor impor. Komposisi kimia teripang secara umum dapat dilihat pada Tabel 1.

Tabel 1. Komposisi Kimia Teripang Segar

\begin{tabular}{cccc}
\hline No & Unsur Kimia & Nilai & Satuan \\
\hline 1 & Air & 82,00 & $\%$ \\
2 & Protein & 8,60 & $\%$ \\
3 & Lemak & 1,70 & $\%$ \\
4 & Abu & 4,80 & $\%$ \\
5 & Karbohidrat & 3,08 & $\%$ \\
6 & Kalsium & 23,00 & $\mathrm{~g}$ \\
7 & Fosfor & 770,00 & $\mathrm{mg}$ \\
8 & Zat Besi & 91,00 & $\mathrm{mg}$ \\
9 & Natrium & 450,00 & $\mathrm{mg}$ \\
10 & Kalium & 0,04 & $\mathrm{mg}$ \\
11 & Vitamin A & 0,07 & $\mathrm{mg}$ \\
12 & Vitamin B & 0,40 & $\mathrm{mg}$ \\
13 & Thamin & 0,10 & $\mathrm{mg}$ \\
14 & Riboflavin & 0,34 & $\mathrm{mg}$ \\
15 & Niasin & 9,90 & $\mathrm{mg}$ \\
\hline
\end{tabular}

Sumber : Dirjen Kelautan dan Perikanan, (1993)

Wibowo (2000) menjelaskan bahwa mengarami teripang dapat dilakukan dengan 2 cara yaitu: penggaraman kecil (dry salting) dan penggaraman basah (brine salting), hal ini dilakukan sebelum teripang di asapi. Penggaraman menyebabkan daging teripang menjadi lebih menyatu, karena garam menekan air dan menyatukan protein dalam daging teripang. Konsentrasi garam dapat menghambat pertumbuhan bakteri. Disamping itu garam juga menyebabkan daging teripang menjadi enak. Untuk mendapatkan teripang asap yang bermutu baik larutan garam digunakan harus mempunyai kejenuhan antara 70 $80 \%$. Larutan diatas $100 \%$ akan merusak produk yaitu dengan terbentuknya Kristalkristal garam di atas permukaan teripang. Sebaliknya bila menggunakan larutan garam yang kejenuhannya di bawah 50\% akan menghasilkan teripang asap yang kurang baik mutunya.

Pengasapan adalah salah satu cara memasak, memberi aroma, atau proses pengawetan makanan, terutama daging, ikan dan hasil laut lainnya. Makanan diasapi dengan panas dan asap yang dihasilkan dari pembakaran kayu, dan tidak diletakkan dekat dengan api agar tidak terpanggang atau terbakar. Sebelum diasapi, biasanya produk direndam di dalam air garam. Beberapa jenis ikan tidak perlu direndam lebih dulu di dalam air garam, Setelah dikeringkan, selanjutnya digantung di tempat pengasapan yang biasanya memiliki cerobong asap. Bahan yang digunakan untuk pengasapan menggunakan kayu yang memiliki aroma kayu yang harum seperti kayu pohonek. Pada saat pengasapan berlangsung sebaiknya dilakukan dengan cara menjaga atau mengawasi agar teripang yang diasapkan merata. Pada saat pengasapan api yang digunakan tidak boleh terlalu besar diusahakan yang digunakan cuman asapnya saja sehingga proses pengasapan sesuai dengan yang diinginkan dan waktu yang digunakan pada saat pengasapan sesuai dengan besar kecilnya bahan yang diasapkan. Komposisi kimia asap dapat dilihat pada tabel 2 .

Tabel 2. Komposisi Kimia Asap

\begin{tabular}{clc}
\hline No & \multicolumn{1}{c}{ Senyawa } & $\begin{array}{c}\text { Kandungan } \\
(\mathbf{p p m})\end{array}$ \\
\hline 1 & Formaldehida & $25-40$ \\
2 & Aldehida & $140-180$ \\
3 & Asam format & $90-125$ \\
4 & Asam asetat & $460-500$ \\
5 & Fenol & $20-30$ \\
6 & Keton & $190-200$ \\
\hline
\end{tabular}

Sumber : Wahyuni, (2009)

Penelitian ini bertujuan untuk mengetahui mutu kimia teripang hitam asap dengan berbagai konsentrasi larutan garam yang berbeda. Sedangkan manfaat penelitian ini diharapkan dapat memberikan informasi ilmiah tentang analisa mutu kimia teripang asap. 


\section{METODE PENELITIAN}

Penelitian dilaksanakan di

Laboratorium Teknologi Hasil Perikanan Sekolah Tinggi Perikanan dan Kelautan (STPL) Palu. Sedangkan untuk analisa kimia dilakukan di Laboratorium Nutrisi Pakan dan Ternak Fakultas Pertanian Universitas Tadulako. Alat yang digunakan dalam penelitian adalah pisau, talenan, kompor gas, belanga rebusan, ember, nampan plastik, erlenmeyer, bunsen, oven, gegep, tanur listrik, desikator, beaker glass, panci, pan almunium, cawan porselin, gelas ukur, evaporator, labu detruksi, timbangan elektrik, timbangan digital, timbangan manual, labu ukur, jepitan, corong bugner, pipet tetes, buret asam, labu semprot.

Bahan utama yang digunakan dalam penelitian ini adalah teripang hitam (Holothuria vacabunda) yang diperoleh dari perairan Teluk Tomini Kabupaten Parigi Moutong, garam dapur, tempurung kelapa sebagai bahan bakar. Bahan lainnya seperti air sebagai pembersih, akuades, petroleum ether, $\mathrm{K}_{2} \mathrm{SO}_{4}$ (kalium sulfat), $\mathrm{CuSO}_{4}$ (tembaga sulfat), $\mathrm{H}_{2} \mathrm{SO}_{4}$ (asam sulfat), $\mathrm{NaOH}$ (natrium hidroksida), $\mathrm{H}_{3} \mathrm{BO}_{3}$ (asam borat), $\mathrm{HCl}$ (asam klorida), metil red, dan metil blue.

Rancangan percobaan yang digunakan dalam penelitian ini adalah Rancangan Acak Lengkap (RAL) dengan kosentrasi larutan garam yang berbeda sebagai perlakuan yang terdiri atas empat (4) taraf yaitu :

$\mathrm{TA}_{1}$ : Konsentrasi larutan garam $5 \%$ $\mathrm{TA}_{2}$ : Konsentrasi larutan garam $10 \%$ $\mathrm{TA}_{3}$ : Konsentrasi larutan garam $15 \%$ $\mathrm{TA}_{4}$ : Konsentrasi larutan garam $20 \%$ Masing-masing perlakuan (lama perendaman) diulang sebanyak empat (4) kali sehingga diperoleh jumlah satuan percobaan sebanyak 16 unit percobaan.

Untuk lebih jelasnya diagram alir pengolahan teripang asap dapat dilihat pada Gambar 1.

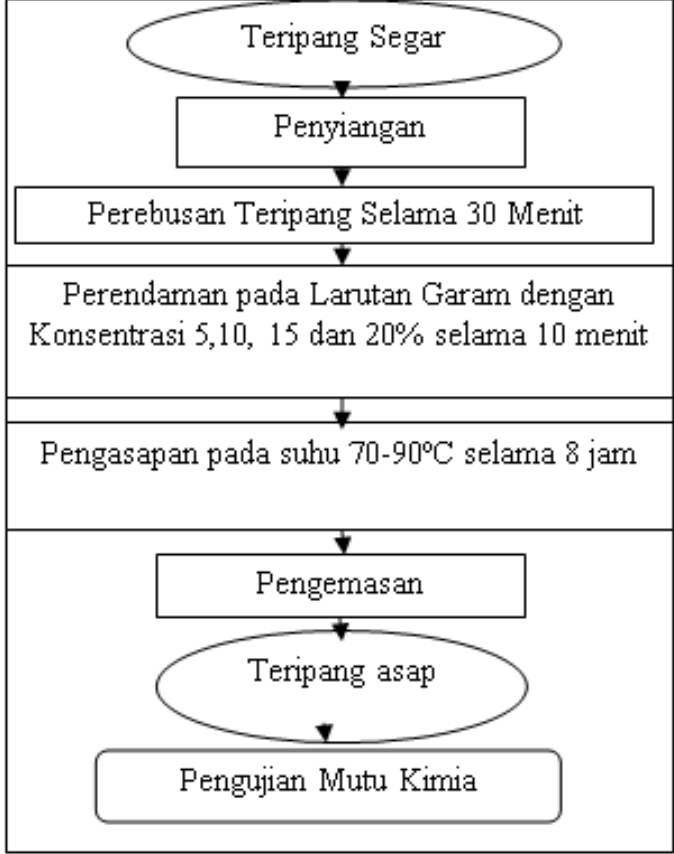

Gambar 1. Diagram Alir Pengolahan Teripang Asap

\section{Peubahan yang diamati Analisis kadar air}

Mallioy (2004) menjelaskan bahwa cawan timbang dikeringkan terlebih dahulu selama 1 jam dalam oven suhu $105^{\circ} \mathrm{C}$, didinginkan menggunakan eksikator dan ditimbang (x). Penimbangan sampel sebanyak 5 gram (y), siapkan cawan untuk ditimbang, kemudian dioven selama $4-6$ jam dengan suhu $105^{\circ} \mathrm{C}$, dinginkan menggunakan eksikator dan ditimbang akhir. Pekerjaan ini diulang sampai 3 kali, hingga dicapai berat konstan (z). Adapun rumus penentuan kadar air sebagai berikut :

$$
\text { Kadar Air }=\frac{(x+y-z)}{y} \times 100 \%
$$

Keterangan : $\mathrm{x}=$ Berat cawan

$$
\begin{aligned}
& \mathrm{y}=\text { Berat sampel } \\
& \mathrm{z}=\begin{array}{c}
\text { Berat sampel }+ \text { cawan } \\
\text { setelah pemanasan }
\end{array}
\end{aligned}
$$

\section{Analisis kadar abu}

Mallioy (2004) menjelaskan bahwa analisa kadar abu dimulai dengan mengeringkan cawan porselin menggunakan oven $105^{\circ} \mathrm{C} / \mathrm{jam}$, menimbang 
berat awal (x) setelah didinginkan menggunakan eksikator. Sebelum ditimbang sampel dimasukan ke cawan porselin sebanyak 5 gram (y). Sampel didinginkan dalam eksikator setelah sampel diangkat dari tanur listrik yang menggunakan suhu $400-600^{\circ} \mathrm{C}$, proses akhir sampel ditimbang kembali. Adapun rumus penentuan kadar abu menggunakan rumus sebagai berikut:

$$
\text { Kadar Abu }=\frac{(\mathrm{z}-\mathrm{x})}{\mathrm{y}} \times 100 \%
$$

Keterangan : $\mathrm{x}=$ Berat cawan

$$
\begin{aligned}
& \mathrm{y}=\text { Berat sampel } \\
& \mathrm{z}=\begin{array}{c}
\text { Berat sampel }+ \text { cawan } \\
\text { setelah pemanasan }
\end{array}
\end{aligned}
$$

\section{Analisis kadar protein}

Farid (2007) menjelaskan bahwa analisa protein adalah kadar nitrogen diukur menggunakan metode makro Kjeldahl. Tahap analisa protein yaitu : Proses Destruksi, Destilasi, Titrasi

Cara Kerja :

1. Kira-kira sebanyak 0.3 g sampel (X) sudah melalui proses penimbangan yang ditimbang dengan alat penimbang analitik, setelah menyiapkan labu destruksi sampel dimasukan. Tambahkan katalis 3 sendok dengan campuran selenium $4 \mathrm{~g}+\mathrm{CuSO}_{4} .5 \mathrm{H}_{2} \mathrm{O} 3 \mathrm{~g}$ $+\mathrm{Na}_{2} \mathrm{SO}_{4} 190 \mathrm{~g}$ serta $20 \mathrm{ml} \mathrm{H} \mathrm{H}_{2} \mathrm{SO}_{4}$ pekat secara homogen. Memanaskan campuran menggunakan alat destruksi dengan posisi low 10 menit, medium 5 menit kemudian hight sampai larutannya menjadi jernih atau hijau kekuningan.

2. Setelah itu tahap destilasi yaitu melakukan proses penyulingan sampai $2 / 3$ dari cairan dalam labu penyuling telah menguap. labu destruksi didinginkan dan larutan tersebut di masukkan ke dalam labu penyuling dan diencerkan dengan $300 \mathrm{ml}$ aquadest yang tidak mengandung N. Tambahkan beberapa butir batu didih dan larutan dijadikan basa dengan menambahkan kira-kira $100 \mathrm{ml} \mathrm{NaOH} \mathrm{33 \% .} \mathrm{Kemudian}$ labu penyuling dipasang dengan cepat di atas alat penyuling.

3. Proses ini hasil sulingan diambil dari kelebihan $\mathrm{H}_{2} \mathrm{SO}_{4}$ yang dititer yang menggunakan larutan $\mathrm{NaOH} 0.3 \mathrm{~N}$ yang dimasukan dalam labu erlenmeyer. Secara otomatis proses ini berhenti ketika ada perubahan warna biru kehijauan. Volume $\mathrm{NaOH}$ dicatat ( $\mathrm{z}$ ml ), kemudian dibandingkan dengan titar blanko ( $\mathrm{y} \mathrm{ml}$ ).

Adapun rumus penentuan kadar protein kasar sebagai berikut:

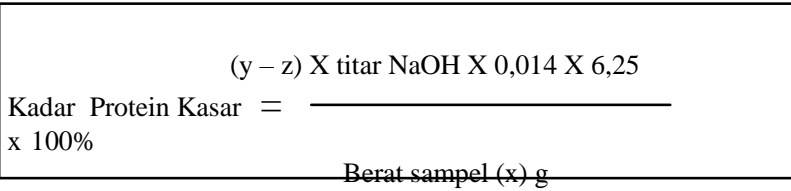

Keterangan :

$\mathrm{x}$ : Volume titrasi contoh

$\mathrm{y}:$ Volume titrasi blangko

\section{HASIL DAN PEMBAHASAN}

\section{Kadar Air}

Rata-rata kadar air teripang hitam asap pada kosentrasi garam yang berbeda yakni dengan kosentrasi garam 5\% ( $\left.\mathrm{TA}_{1}\right)$ sebesar 12.09\%, kosentrasi garam 10\% $\left(\mathrm{TA}_{2}\right)$ sebesar $10.17 \%$, kosentrasi garam $15 \%\left(\mathrm{TA}_{3}\right)$ sebesar $10.06 \%$, dan kosentrasi garam $20 \%\left(\mathrm{TA}_{4}\right)$ sebesar $9.44 \%$. Rata-rata kadar air teripang hitam tersebut dapat dilihat pada Gambar 2.

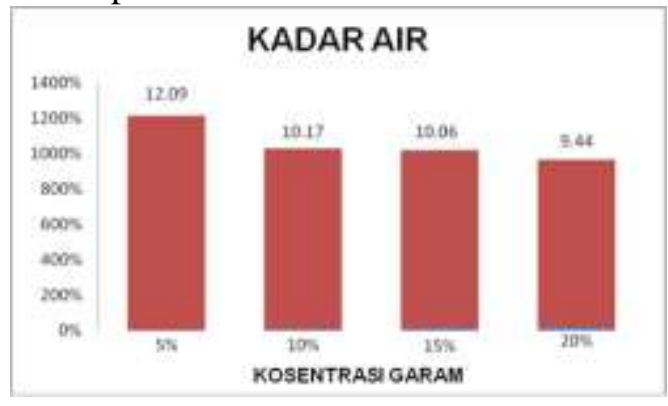

Gambar 2. Rata-rata kadar air teripang hitam Asap

Diagram di atas menunjukan bahwa kadar air teripang hitam asap pada kosentrasi garam yang berbeda berkisar antara $9.44-12.09 \%$. Kadar air teripang 
hitam asap pada kosentrasi garam yang berbeda dengan perlakuan $5 \% \quad\left(\mathrm{TA}_{1}\right)$ sebesar $12.09 \%$ merupakan kadar air yang tertinggi yang diperoleh dalam penelitian ini. Sedangkan kadar air yang terendahnya pada kosentrasi garam $20 \%\left(\mathrm{TA}_{4}\right)$ sebesar 9.44\%. Hasil analisis sidik ragam menunjukan bahwa kosentrasi garam yang berbeda memberikan pengaruh sangat nyata terhadap kadar air teripang hitam asap yang dihasilkan. Hal ini dikarenakan pemberian garam yang berbeda sehingga hasil yang didapat pada penelitian ini berbeda pula. Tingkat kelembaban suatu produk pangan sangat ditentukan oleh cara, waktu pengeringan. Warkoyo (2006), menyatakan bahwa dalam proses pengeringan dapat meningkatkan tekanan uap air dalam bahan pangan sehingga dapat menguap air dari permukaan bahan yang ada didalamnya. Dalam penelitian ini semakin tinggi kosentrasi garam yang digunakan maka semakin rendah kadar air yang didapatkan begitu pula sebaliknya ini dikarenakan kadar air yang terdapat pada teripang lebih banyak dan kandungan yang terdapat pada garam membuat kosentrasi garam yang digunakan yaitu $20 \%$ lebih besar hasilnya.

\section{Kadar Abu}

Rata-rata kadar abu teripang hitam asap yang diperoleh dalam penelitian ini yakni dengan kosentrasi garam 5\% ( $\left.\mathrm{TA}_{1}\right)$ sebesar 21.83\%, kosentrasi garam $10 \%$ $\left(\mathrm{TA}_{2}\right)$ sebesar $22.40 \%$, kosentrasi garam $15 \%\left(\mathrm{TA}_{3}\right)$ sebesar $22.82 \%$, dan kosentrasi garam $20 \%\left(\mathrm{TA}_{4}\right)$ sebesar $25.15 \%$. Ratarata kadar abu teripang hitam tersebut dapat dilihat pada gambar 3 .

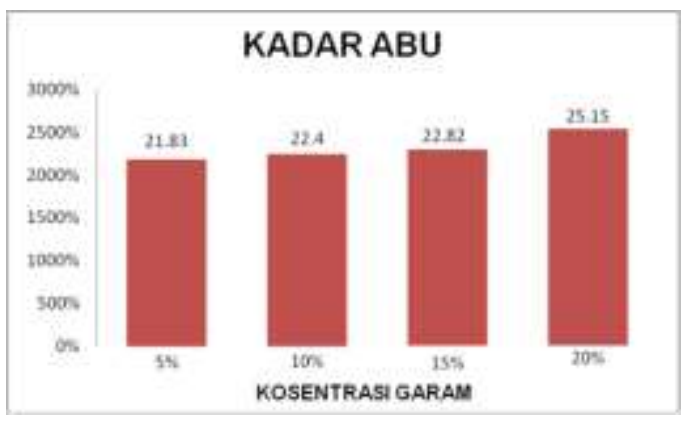

Gambar 3. Rata-rata kadar abu teripang hitam Asap
Diagram tersebut di atas menunjukan bahwa kadar abu tertinggi diperoleh pada kosentrasi garam $20 \% \quad\left(\mathrm{TA}_{4}\right)$ sebesar $25.15 \%$ serta terendah diperoleh pada kosentrasi 5\% $\left(\mathrm{TA}_{1}\right)$ sebesar $21.83 \%$. kandungan mineral yang terdapat pada teripang hitam terlarut dalam air selama proses penggaraman sehingga kandungan mineral pada kosentrasi garam 5\% lebih rendah. Menurut Sudarmadji (1984) dalam Warkoyo (2006), besarnya kadar abu dalam suatu bahan pengan menunjukan besarnya kandungan mineral dalam bahan pangan tersebut. Namun kadar abu juga ditunjukan dengan adanya unsur logam yang larut dalam dan masih menempel pada bahan.

\section{Kadar Protein}

Rata-rata kadar protein teripang hitam asap yang diperoleh dalam penelitian ini yakni dengan kosentrasi garam 5\% $\left(\mathrm{TA}^{1}\right)$ sebesar $7.51 \%$, kosentrasi garam $10 \%\left(\mathrm{TA}^{2}\right)$ sebesar $8.41 \%$, kosentrasi garam $15 \%\left(\mathrm{TA}^{3}\right)$ sebesar $8.49 \%$, dan kosentrasi garam 20\% $\left(\mathrm{TA}^{4}\right)$ sebesar 8.78\%. Rata-rata Kadar Protein teripang hitam asap tersebut dapat dilihat pada Gambar 4.

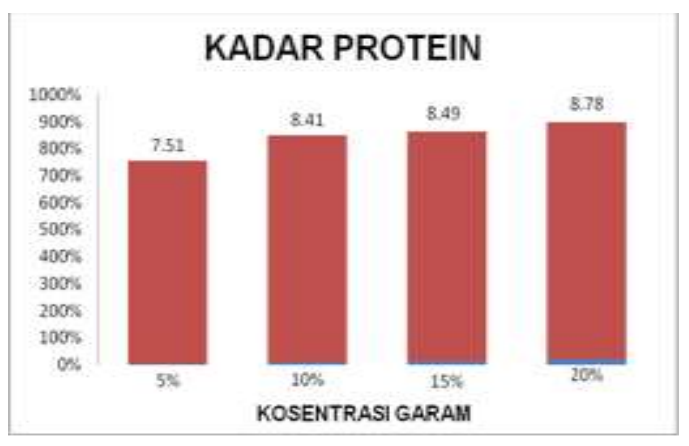

Gambar 4. Rata-rata Kadar Protein teripang hitam asap

Diagram di atas menunjukan bahwa kadar protein teripang hitam asap berkisar antara $7.51-8.78 \%$. Kadar protein teripang hitam pada kosentrasi garam $20 \%\left(\mathrm{TA}^{4}\right)$ sebesar $8.78 \%$ merupakan kadar protein tertinggi yang diperoleh dalam penelitian ini. Sedangkan kadar protein yang terendah diperoleh darikosentrasi garam 5\% ( $\left.\mathrm{TA}^{1}\right)$ sebesar $7.51 \%$ 


\section{KESIMPULAN}

Berdasarkan hasil dan pembahasan maka dapat ditarik kesimpulan bahwa :

1. Kadar air tertinggi yakni 5\% sebesar $12.09 \%$ sedangkan untuk kadar air yang terbaik terdapat pada kosentrasi garam $20 \%$ sebesar $9.44 \%$

2. Kadar abu tertinggi yakni $20 \%$ sebesar $25.15 \%$ sekaligus yang terbaik terdapat pada kosentrasi garam $20 \%$ sebesar $25.15 \%$

3. Kadar protein tertinggi yakni $20 \%$ sebesar $8.78 \%$ dan sekaligus yang terbaik terdapat pada kosentrasi garam $20 \%$ sebesar $8.78 \%$

\section{UCAPAN TERIMAKASIH}

Penulis menyampaikan terimakasih banyak kepada Sekolah Tinggi Perikanan dan Kelautan palu yang telah meberikan bantuan kepada penulis dalam melakukan penelitian.

\section{REFERENSI}

Dirjen Perikanan dan Kelautan. 1993. Budidaya dan Pengolahan Teripang. Jakarta.

Farid, 2007. Pengaruh Injeksi Antemortem Enzim Dalam Meningkatkan Kualitas Daging Layer Afkir Pada Otot Yang Berbeda. Fakultas Pertanian. Universitas Sebelas Maret.

Mallioy I. Y., 2004. Penerimaan Konsumen Terhadap Produk Bakso Ikan Layang (Decapterus sp.) dengan Penanganan Awal Bahan Baku Berbeda. Teknologi Hasil Perikanan. Universitas Sam Ratulangi, Manado.

Wahyuni. S. 2009. Pengaruh Pengolahan Tradisional Terhadap Mutu dan Gizi Ikan Teri (Stolephorus sp) Asap. Tesis Program Pascasarjana Institut Pertanian Bogor.

Warkoyo,. 2006. Pengolahan Sabut Kelapa Dengan Metode Perendaman. Departemen Perindustrian. Badan Penelitian dan Pengembangan Industri Manado.

Wibowo. S. 2000. Industri Pengasapan Ikan. Niaga. Jakarta 